\title{
PROPOSED POLICY OF MEDICATION INVENTORY SYSTEM IN PHARMACY INSTALLATION (Case Study in SEMEN PADANG HOSPITAL)
}

\section{FINAL PROJECT REPORT}

A Proposal submitted in fulfillment of the requirement for the award od the degree of Bachelor in Department of Industrial Engineering, Faculty of Engineering, Andalas University

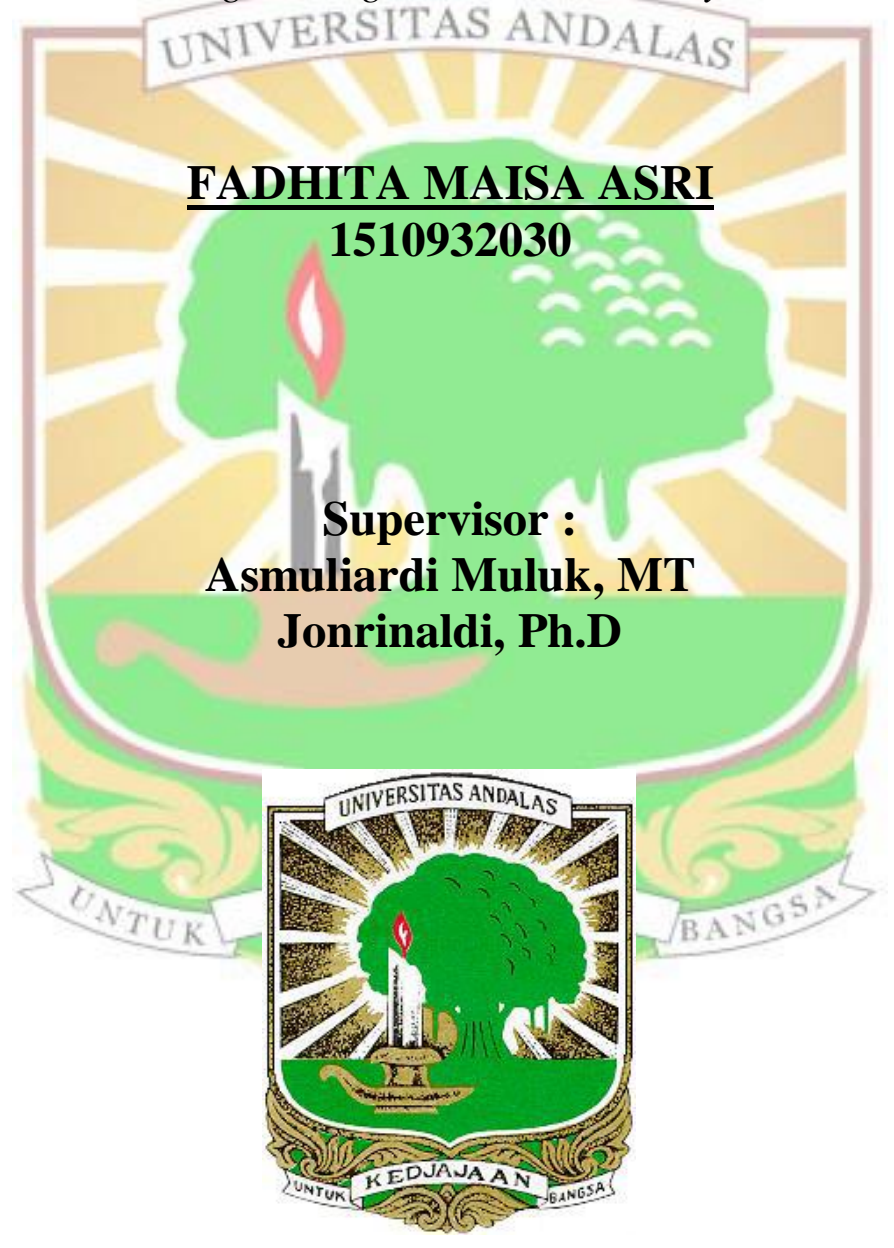

DEPARTMENT OF INDUSTRIAL ENGINEERING

FACULTY OF ENGINEERING

ANDALAS UNIVERSITY

PADANG

2019 


\begin{abstract}
Inventory for companies are very important. Fluctuation and uncertainty demand of a product requiring an agency to have inventory stock to fulfil the demand of the product. But the existence of these inventories are often considered a waste. Therefore, inventory management is needed so that the demand of a product can be fulfilled effectively and efficiently. Hospital must be aware with the management in pharmacy especially on pharmacy inventory management in pharmacy installation. Semen Padang Hospital is a facilities that provides health service that has one pharmacy as the central place that is responsible for the procurement, storage and distribution of medication throughout the hospital. But in current conditions, Semen Padang Hospital could not fulfill the demand of the medicine for its patients because there are out of stocks for several medicines at the inventory. This condition happened because there is 4 no policy to manage the procurement of medication in Semen Padang Hospital. This condition affect to the period of getting those required medicines for the patients where most of them have a pending issue. So, the patients could not receive the medicine in time. To anticipate the stockout condition of medicines, the managerial in Semen Padang Hospital implement a solution which is ordering the medicines from partnered hospital and drugstore with the price is $20 \%$ higher than normal price. However, this solution gives a negative impact for its financial aspect because it spent more cost than it should be and their quality of service.
\end{abstract}

Based on the problem that explained above, a new inventory policy is needed to reduce the number of stockout medicines and to minimize the total cost of inventory that incurred by the hospital. First the medicines will be classified into three classes by using $\mathrm{ABC}$ analysis. The proposed medication inventory policy for class A and vital medicines are solved using probabilistic inventory model (EOQ + Safety stock) and for class B and C solved using Joint Replenishment. This models are used because of the assumptions are suitable with the actual condition in Semen Padang Hospital.

$$
\text { YNTUK KEDJAJAAN }
$$

After the medicine classified into three classes, in class A there are $19.896 \%$ from all medicine that consume $78.403 \%$ of investment, for class B there are $29.909 \%$ from all medicine and consume $19.23 \%$ of investment. While class C consist $50.195 \%$ of medicine and consume only $2.36 \%$ of investment. In term of medication, the classes needs a further classification based on its level of importance. So there will be nine proposed policies and different treatment for each classes. By using proposed inventory policy, which are Probabilistic Inventory Model (EOQ + Safety Stock) and Joint Replenishment Model after adjustment, Semen Padang Hospital has saving money potential as much Rp 202,136,948 or $63.27 \%$ of the cost spend based on the current policy that applied right now in three months (October - December 2018).

Keywords: EOQ, medication, inventory control 


\begin{abstract}
ABSTRAK
Persediaan bagi sebuah instansi merupakan hal yang sangat penting. Terdapatnya fluktuasi dan ketidakpastian permintaan dari suatu produk mengharuskan sebuah instansi memiliki persediaan untuk dapat memenuhi kebutuhan atas produk tersebut. Namun keberadaan dari persediaan ini sering dianggap sebagai pemborosan. Oleh karena itu, pengelolaan persediaan diperlukan agar kebutuhan dari suatu produk dapat terpenuhi secara efektif dan efisien. Pengelolaan persediaan obat dalam sebuah instalasi farmasi merupakan salah satu hal krusial yang harus diperhatikan oleh rumah sakit. Rumah Sakit Semen Padang merupakan sebuah institusi pelayanan di bidang kesehatan yang memiliki satu instalasi farmasi sebagai sentral yang bertanggung jawab dalam pengelolaan obat. Tetapi pada kondisi saat ini, tingkat ketersediaan obat masih belum memenuhi permintaan obat di rumah sakit ini karena masih banyak obat yang mengalami stock out. Hal ini disebabkan karena belum adanya kebijakan persediaan yang diterapkan oleh Rumah Sakit Semen Padang. Akibatnya, banyak dari pasien yang menerima resep pending, dimana pasien harus menunggu untuk mendapatkan obat yang dibutuhkan. Untuk mengantisipasi kekurangan obat, pihak rumah sakit membeli dari rumah sakit atau apotik rekanan yang harganya $20 \%$ lebih tinggi dibandingkan dengan harga normal. Permasalahan ini tentu akan sangat memberikan pengaruh buruk untuk berbagai aspek seperti finansial dan kualitas dari pelayanan di rumah sakit ini.
\end{abstract}

Berdasarkan permasalah yang telah dijelaskan diperlukan usulan kebijakan persediaan untuk mengurangi jumlah stock out obat dan meminimasi total biaya persediaan yang dikeluarkan oleh rumah sakit. Kebijakan manajemen persediaan dilakukan dengan menggunakan $A B C$ analysis. Usulan kebijakan persediaan diselesaikan dengan menggunakan model persediaan probabilistik (EOQ + Safety Stock) untuk kelas A dan kategori obat vital dan kebijakan persediaan menggunakan Joint Replenishment Model untuk kelas B dan C. Model ini digunakan karena asumsi yang digunakan pada model ini sesuai dengan keadaan aktual yang ada di Rumah Sakit Semen Padang.

Setelah obat dikelompokkan ke dalam tiga kelompok menggunakan analisis ABC, pada kelas A terdapat $19.896 \%$ jenis obat dengan total nilai investasi $78.403 \%$, untuk kelas B terdapat $29.909 \%$ jenis obat dengan nilai investasi sebesar 19.23\%. sedangkan untuk kelas C terdiri dari $50.195 \%$ jenis obat yang memiliki nilai investasi sebesar 2.36\%. Dalam konteks obat, pengelompokan membutuhkan klasifikasi lebih lanjut berdasarkan tingkat kepentingannya. Jadi akan ada sembilan kebijakan yang diusulkan dan perlakuan berbeda untuk masing-masing kelas. Berdasarkan hasil perhitungan menggunakan kebijakan usulan dengan penyesuaian, Semen Padang Hospital dapat menghemat biaya sebesar Rp 202,136,948 atau $63.27 \%$ dari total biaya yang dikeluarkan berdasarkan kebijakan yang diterapkan saat ini pada tiga bulan terakhir (Oktober-Desember 2018).

Kata Kunci: EOQ, obat, pengendalian persediaan 